\title{
Arabinoxylan Compound MGN3
}

National Cancer Institute

\section{Source}

National Cancer Institute. Arabinoxylan Compound MGN3. NCI Thesaurus. Code C1879.

An arabinoxylane polysaccharide composed of the hemicellulose-Beta extract of rice bran, treated with enzymes from Shiitake mushrooms, that exerts antitumor and antiviral activity by increasing the level of natural killer cells activation. ( $\mathrm{NCl})$ 